\title{
TOWARD AN IMPROVED UNDERSTANDING OF STRUCTURE AND MAGNETISM IN NEPTUNIUM AND PLUTONIUM PHOSPHONATES AND SULFONATES
}

\author{
Prof. Thomas E. Albrecht-Schmitt \\ Department of Chemistry and Biochemistry and Center for Actinide Science \\ Auburn University, Auburn, AL 36849 \\ U.S. Department of Energy \\ Office of Basic Energy Sciences \\ Heavy Elements Program (Grant DE-FG02-01ER15187)
}

Final Report

\section{Ph.D.'s supported:}

Travis H. Bray (post-doc LBNL and Argonne)

Yaqin $\mathrm{Yu}$

Anna-Gay D. Nelson (post-doc with Rod Ewing at Michigan)

Andrea Alsobrook (post-doc at SRNL with Dave Hobbs)

Jie Ling (post-doc with Peter Burns at Notre Dame. Now employed by Li Battery Company)

Pius O. Adelani (post-doc with Peter Burns at Notre Dame)

Tatiana Y. Shvareva (staff scientist with Alex Navrotsky)

Tyler Sullens (Professor at Christopher Newport University)

Thomas Shehee (post-doc at Savannah River) 
Philip M. Almond (Staff Scientist at SRNL)

Richard E. Sykora (Professor at U. South Alabama)

Amanda C. Bean (Staff Scientist at LANL)

\section{List of Publications}

69. T. E. Albrecht-Schmitt, "Structural Crystallography of Inorganic Oxysalts. IUCr Monographs on Crystallography No. 22. By Sergey V. Krivovichev,” Book Review. Angewandte Chemie, Int. Ed. 2009, 48, 5237. Invited Article.

68. A. N. Alsobrook, T. E. Albrecht-Schmitt, "Phosphonoacetate as a Ligand for Constructing Layered and Framework Alkali Metal Uranyl Compounds," Inorganic Chemistry, 2009, 48, 11079-11084.

67. S. Wu, J. Ling, S. Wang, S. Skanthakumar, L. Soderholm, T. E. Albrecht-Schmitt, E. V. Alekseev, S. V. Krivovichev, W. Depmeier, "Uranium(VI) Adopts a Tetraoxido Core," European Journal of Inorganic Chemistry 2009, 27, 4039-4042.

66. A.-G. D. Nelson, T. H. Bray, F. A. Stanley, and T. E. Albrecht-Schmitt, "Periodic Trends in Actinide Phosphonates: Divergence and Convergence between Thorium, Uranium, Neptunium, and Plutonium Systems," Inorganic Chemistry, 2009, 48, 4530-4535.

65. P. O. Adelani and T. E. Albrecht-Schmitt, "Uranyl Diphosphonates with Pillared Structures," Inorganic Chemistry, 2009, 48, 2732-2734.

64. Y. Yu, K. Jiang, and T. E. Albrecht-Schmitt, " $\left[\mathrm{Hg}_{5} \mathrm{O}_{2}(\mathrm{OH})_{4}\right]\left[\left(\mathrm{UO}_{2}\right)_{2}\left(\mathrm{AsO}_{4}\right)_{2}\right]$ : A Complex Mercury(II) Uranyl Arsenate," Journal of Solid State Chemistry, 2009, 182, 1867-1871.

63. Y. Yu, W. Zhan, T. E. Albrecht-Schmitt, " $\left[\mathrm{H}_{2} \text { bipy }\right]_{2}\left[\left(\mathrm{UO}_{2}\right)_{6} \mathrm{Zn}_{2}\left(\mathrm{PO}_{3} \mathrm{OH}\right)_{4}\left(\mathrm{PO}_{4}\right)_{4}\right] \cdot \mathrm{H}_{2} \mathrm{O}$ : An Open-Framework Uranyl Zinc Phosphate Templated by Diprotonated 4,4'-bipyridyl," Inorganic Chemistry, 2008, 47, 9050-9054.

62. A.-G. D. Nelson, T. H. Bray, and T. E. Albrecht-Schmitt, "Capitalizing on Differing Coordination Environments and Redox Potentials for Preparing an Ordered Heterobimetallic U(VI)/Np(IV) Diphosphonate," Angewandte Chemie, Int. Ed. 2008, 47, $6252-6254$. 
61. A.-G. D. Nelson, T. H. Bray, W. Zhan, R. G. Haire, and T. E. Albrecht-Schmitt, "Further Examples of the Failure of Surrogates to Properly Model the Structural and Hydrothermal Chemistry of Transuranium Elements: Insights Provided by Uranium and Neptunium Diphosphonates," Inorganic Chemistry, 2008, 47, 4945-4951.

60. A. N. Alsobrook, W. Zhan, and T. E. Albrecht-Schmitt, "On the Use of Bifunctional Phosphonates for the Preparation of Heterobimetallic 5f-3d Systems," Inorganic Chemistry, 2008, 47, 5177-5183.

59. R. E. Sykora, P. Khalifah, Z. Assefa, T. E. Albrecht-Schmitt, and R. G. Haire, "Magnetic Interactions in Dimeric Lanthanide Iodates: Structures, Raman Spectroscopy, and Magnetism of $\mathrm{Ln}\left(\mathrm{IO}_{3}\right)_{3}(\mathrm{Ln}=\mathrm{Gd}, \mathrm{Er})$ and Magnetism of $\mathrm{Yb}\left(\mathrm{IO}_{3}\right)_{3}$," Journal of Solid State Chemistry, 2008, 181, 1867-1875.

58. T. H. Bray, J. D. Gorden, and T. E. Albrecht-Schmitt, "Synthesis and Structure of $\left[\mathrm{C}_{6} \mathrm{H}_{14} \mathrm{~N}_{2}\right]\left[\left(\mathrm{UO}_{2}\right)_{4}\left(\mathrm{HPO}_{4}\right)_{2}\left(\mathrm{PO}_{4}\right)_{2}\left(\mathrm{H}_{2} \mathrm{O}\right)\right] \cdot \mathrm{H}_{2} \mathrm{O}$ : An Expanded Open-Framework AmineBearing Uranyl Phosphate," Journal of Solid State Chemistry, 2008, 181, 2199-2204.

57. T. H. Bray, S. Skanthakumar, L. Soderholm, R. E. Sykora, R. G. Haire, and T. E. Albrecht-Schmitt, "Hydrothermal Synthesis, Structure, and Magnetic Properties of $\mathrm{Pu}\left(\mathrm{SeO}_{3}\right)_{2}$," Journal of Solid State Chemistry, 2008, 181, 493-498.

56. Y. Yu and T. E. Albrecht-Schmitt, "Incorporation of Tetrahedral Co(II) into a MixedMetal Uranyl Phosphate Framework: Synthesis and Structure of $\mathrm{K}_{2}\left[\mathrm{UO}_{2} \mathrm{Co}\left(\mathrm{PO}_{4}\right)_{2}\right] \cdot \mathrm{H}_{2} \mathrm{O}$," Solid State Sciences, 2008, 10, 821-824. Cover Article

55. T. H. Bray, A.-G. D. Nelson, G. B. Jin, R. G. Haire, and T. E. Albrecht-Schmitt, "In Situ Hydrothermal Reduction of $\mathrm{Np}(\mathrm{VI})$ as a Route to $\mathrm{Np}(\mathrm{IV})$ Phosphonates," Inorganic Chemistry, 2007, 46, 10959-10961.

54. Y. Yu, W. Zhan, and T. E. Albrecht-Schmitt, "One- and Two-Dimensional Silver and Zinc Uranyl Phosphates Containing Bipyridyl Ligands," Inorganic Chemistry, 2007, 46, 10214-10220.

53. T. H. Bray, T. A. Sullens, T. Y. Shvareva, R. E. Sykora, R. G. Haire, and T. E. AlbrechtSchmitt, "Product Evolution in the Np(IV) Fluorophosphate System," Journal of Solid State Chemistry, 2007, 180, 79-83.

52. T. H. Bray, J. Ling, E.-S. Choi, J. S. Brooks, J. V. Beitz, R. E. Sykora, R. G. Haire, D. M. Stanbury, and T. E. Albrecht-Schmitt, "Critical Role of Water Content in the 
Formation and Reactivity of Uranium, Neptunium, and Plutonium Iodates Under Hydrothermal Conditions: Implications for the Oxidative Dissolution of Spent Nuclear Fuel," Inorganic Chemistry, 2007, 46, 3663-3668.

51. J. Ling and T. E. Albrecht-Schmitt, "Intercalation of Iodic Acid into the Layered Uranyl Iodate, $\mathrm{UO}_{2}\left(\mathrm{IO}_{3}\right)_{2}\left(\mathrm{H}_{2} \mathrm{O}\right)$," Inorganic Chemistry, 2007, 46, 346-347.

50. T. Y. Shvareva, S. Skanthkumar, L. Soderholm, A. Clearfield, and T. E. AlbrechtSchmitt, "Cs ${ }^{+}$-Selective Ion-Exchange and Magnetic Ordering in a Three-Dimensional Framework Uranyl Vanadium(IV) Phosphate," Chemistry of Materials, 2007, 19, 132 134.

49. T. A. Sullens and T. E. Albrecht-Schmitt, "Thorium Chromate Dihydrate," Acta Crystallogr. E, 2006, 62, i258-i260.

48. Z. Assefa, J. Ling, R. G. Haire, T. E. Albrecht-Schmitt, and R. E. Sykora, "Syntheses, Structures, and Vibrational Spectroscopy of the Two-Dimensional Iodates $\operatorname{Ln}\left(\mathrm{IO}_{3}\right)_{3}$ and $\mathrm{Ln}\left(\mathrm{IO}_{3}\right)_{3}\left(\mathrm{H}_{2} \mathrm{O}\right)(\mathrm{Ln}=\mathrm{Yb}, \mathrm{Lu})$, , Journal of Solid State Chemistry, 2006, 179, 3653-3663.

47. T. H. Bray, J. V. Beitz, A. C. Bean, Y. Yu, and T. E. Albrecht-Schmitt, "Structural Polarity Induced by Cooperative Hydrogen Bonding and Lone-Pair Alignment in the Molecular Uranyl Iodate, $\mathrm{Na}_{2}\left[\mathrm{UO}_{2}\left(\mathrm{IO}_{3}\right)_{4}\left(\mathrm{H}_{2} \mathrm{O}\right)\right]$," Inorganic Chemistry, 2006, 45, 82518257.

46. T. Y. Shvareva and T. E. Albrecht-Schmitt, "A General Route to Three-Dimensional Framework Uranyl Transition Metal Phosphates with Atypical Structural Motifs: The Case Examples of $\mathrm{Cs}_{2}\left\{\left(\mathrm{UO}_{2}\right)_{4}\left[\mathrm{Co}\left(\mathrm{H}_{2} \mathrm{O}\right)_{2}\right]_{2}\left(\mathrm{HPO}_{4}\right)\left(\mathrm{PO}_{4}\right)_{4}\right\}$ and $\mathrm{Cs}_{3+\mathrm{x}}\left[\left(\mathrm{UO}_{2}\right)_{3} \mathrm{CuH}_{4-}\right.$ x $\left.\left(\mathrm{PO}_{4}\right)_{5}\right] \cdot \mathrm{H}_{2} \mathrm{O}$," Inorganic Chemistry, 2006, 45, 1900-1902.

45. R. E. Sykora, Z. Assefa, T. E. Albrecht-Schmitt, and R. G. Haire, "The First Structural Determination of a Trivalent Californium Compound with Oxygen Coordination," Inorganic Chemistry, 2006, 45, 475-477.

44. T. A. Sullens, P. M. Almond, J. A. Byrd, J. V. Beitz, and Thomas E. Albrecht-Schmitt, "Extended Networks, Porous Sheets, and Chiral Frameworks. Thorium Materials Containing Mixed Geometry Anions: Structures and Properties of $\mathrm{Th}\left(\mathrm{SeO}_{3}\right)\left(\mathrm{SeO}_{4}\right)$, $\mathrm{Th}\left(\mathrm{IO}_{3}\right)_{2}\left(\mathrm{SeO}_{4}\right)\left(\mathrm{H}_{2} \mathrm{O}\right)_{3} \cdot \mathrm{H}_{2} \mathrm{O}$, and $\mathrm{Th}\left(\mathrm{CrO}_{4}\right)\left(\mathrm{IO}_{3}\right)_{2}$," Journal of Solid State Chemistry, 2006, 179, 1181-1190. 
43. T. Y. Shvareva, J. V. Beitz, E. C. Duin, and T. E. Albrecht-Schmitt, "Polar OpenFramework Structure, Optical Properties, and EPR of the Mixed-Metal Uranyl Phosphate $\mathrm{Cs}_{2}\left[\mathrm{UO}_{2}\left(\mathrm{VO}_{2}\right)_{2}\left(\mathrm{PO}_{4}\right)_{2}\right] \cdot 0.59 \mathrm{H}_{2} \mathrm{O}$," Chemistry of Materials, 2005, 17, 6219-6222.

42. J. D. Woodward and T. E. Albrecht-Schmitt, "Molten Salt Flux Synthesis and Structure of the New Layered Uranyl Tellurite, $\mathrm{K}_{4}\left[\left(\mathrm{UO}_{2}\right)_{5}\left(\mathrm{TeO}_{3}\right)_{2} \mathrm{O}_{5}\right]$," Journal of Solid State Chemistry, 2005, 178, 2922-2926.

41. T. E. Albrecht-Schmitt, "Actinide Materials Adopt Curvature: Recent Discoveries of Actinide-Based Nanotubules and Nanospheres," Angewandte Chemie 2005, 44, 48364838. Invited Highlight

40. J. D. Woodward, P. M. Almond, and T. E. Albrecht-Schmitt, "Cesium Thorium Silicate, $\mathrm{Cs}_{2} \mathrm{ThSi}_{6} \mathrm{O}_{15}$," Acta Crystallogr. 2005, E61, i58-i60.

39. R. E. Sykora, Z. Assefa, R. G. Haire, and T. E. Albrecht-Schmitt, "Synthesis, Structure, and the Raman and Emission Properties of $\mathrm{Am}\left(\mathrm{IO}_{3}\right)_{3}$ and $\mathrm{Cm}\left(\mathrm{IO}_{3}\right)_{3}$," Inorganic Chemistry, 2005, 44, 5667-5676.

38. T. Y. Shvareva, P. M. Almond, and T. E. Albrecht-Schmitt, "Crystal chemistry and ionexchange properties of the layered uranyl iodate $\mathrm{K}_{[}\left[\mathrm{UO}_{2}\left(\mathrm{IO}_{3}\right)_{3}\right]$," Journal of Solid State Chemistry, 2005, 178, 499-504. Featured on the Cover of the Journal.

37. T. A. Sullens and T. E. Albrecht-Schmitt, "Structure and Properties of the Thorium Vanadyl Tellurate, $\mathrm{Th}\left(\mathrm{VO}_{2}\right)_{2}\left(\mathrm{TeO}_{6}\right)\left(\mathrm{H}_{2} \mathrm{O}\right)_{2}$," Inorganic Chemistry, 2005, 44, 2282-2286.

36. T. Y. Shvareva, T. A. Sullens, T. C. Shehee, and T. E. Albrecht-Schmitt, "Syntheses, Structures, and Ion-Exchange Properties of the Three-Dimensional Framework Uranyl Gallium Phosphates, $\mathrm{Cs}_{4}\left[\left(\mathrm{UO}_{2}\right)_{2}(\mathrm{GaOH})_{2}\left(\mathrm{PO}_{4}\right)_{4}\right] \cdot \mathrm{H}_{2} \mathrm{O}$ and $\mathrm{Cs}\left[\mathrm{UO}_{2} \mathrm{Ga}_{(}\left(\mathrm{PO}_{4}\right)_{2}\right]$," Inorganic Chemistry, 2005, 44, 300-305.

34. R. E. Sykora, Z. Assefa, R. G. Haire, and T. E. Albrecht-Schmitt, "Hydrothermal Synthesis, Structure, Raman Spectroscopy, and Self-Irradiation Studies of ${ }^{248} \mathrm{Cm}\left(\mathrm{IO}_{3}\right)_{3}$," Journal of Solid State Chemistry, 2004, 177, 4413-4419.

33. R. E. Sykora and T. E. Albrecht-Schmitt, "Hydrothermal Synthesis and Crystal Structure of $\mathrm{Cs}_{6}\left[\left(\mathrm{UO}_{2}\right)_{4}\left(\mathrm{~W}_{5} \mathrm{O}_{21}\right)(\mathrm{OH})_{2}\left(\mathrm{H}_{2} \mathrm{O}\right)_{2}\right]$ : A New Polar Uranyl Tungstate," Journal of Solid State Chemistry, 2004, 177, 3729-3734.

32. T. A. Sullens, P. M. Almond, and T. E. Albrecht-Schmitt, "Ethylene Diammonium Dineptunium Decafluoride," Acta Crystallogr. 2004, E60, m973-m975. 
31. E. Jobiliong, Y. Oshima, J. S. Brooks, T. E. Albrecht-Schmitt, "Magnetism and Electron Spin Resonance in Single Crystalline $\beta-\mathrm{AgNpO}_{2}\left(\mathrm{SeO}_{3}\right)$," Solid State Communications, 2004, 132, 337-342.

30. J. D. Woodward, P. M. Almond, and T. E. Albrecht-Schmitt, "Synthesis and Crystal Structures of the Layered Uranyl Tellurites $\mathrm{A}_{2}\left[\left(\mathrm{UO}_{2}\right)_{3}\left(\mathrm{TeO}_{3}\right)_{2} \mathrm{O}_{2}\right](\mathrm{A}=\mathrm{K}, \mathrm{Rb}, \mathrm{Cs})$," Journal of Solid State Chemistry, 2004, 177, 3971-3976.

29. T. A. Sullens, R. A. Jensen, T. Y. Shvareva, and T. E. Albrecht-Schmitt, "Cation-Cation Interactions Between Uranyl Cations in a Polar Open-Framework Uranyl Periodate," Journal of the American Chemical Society, 2004, 126, 2676-2677.

28. P. M. Almond, R. E. Sykora, S. Skanthakumar, L. Soderholm, and T. E. AlbrechtSchmitt, "Hydrothermal Synthesis, Structure, and Magnetic Properties of the MixedValent $\mathrm{Np}(\mathrm{IV}) / \mathrm{Np}(\mathrm{V})$ Selenite, $\mathrm{Np}\left(\mathrm{NpO}_{2}\right)_{2}\left(\mathrm{SeO}_{3}\right)_{3}$, Inorganic Chemistry, 2004, 43, 958963.

27. R. E. Sykora, J. King, A. Illies, and T. E. Albrecht-Schmitt, "Hydrothermal Synthesis, Structure, and Catalytic Properties of $\mathrm{UO}_{2} \mathrm{Sb}_{2} \mathrm{O}_{4}$ " Journal of Solid State Chemistry, 2004, 177, 1717-1722.

26. P. M. Almond and T. E. Albrecht-Schmitt, "Hydrothermal synthesis and crystal chemistry of the new strontium uranyl selenites, $\operatorname{Sr}\left[\left(\mathrm{UO}_{2}\right)_{3}\left(\mathrm{SeO}_{3}\right)_{2} \mathrm{O}_{2}\right] \cdot 4 \mathrm{H}_{2} \mathrm{O}$ and $\mathrm{Sr}\left[\mathrm{UO}_{2}\left(\mathrm{SeO}_{3}\right)_{2}\right] "$ American Mineralogist, 2004, 89, 976-980.

25. R. E. Sykora, S. M. McDaniel, and T. E. Albrecht-Schmitt, "Hydrothermal Synthesis and Structure of $\mathrm{K}_{6}\left[\left(\mathrm{UO}_{2}\right)_{4}\left(\mathrm{CrO}_{4}\right)_{7}\right] \cdot 6 \mathrm{H}_{2} \mathrm{O}$ : A Layered Uranyl Chromate with a New Uranyl Sheet Topology," Journal of Solid State Chemistry, 2004, 177, 1431-1436.

24. A. C. Bean, B. L. Scott, T. E. Albrecht-Schmitt, and W. Runde, "Intercalation of KCl Into Layered Neptunyl and Plutonyl Iodates," Journal of Solid State Chemistry, 2004, 176, 1346-1351.

23. R. E. Sykora, L. Deakin, A. Mar, S. Skanthakumar, L. Soderholm, and T. E. AlbrechtSchmitt, "Isolation of Intermediate-Valent Ce(III)/Ce(IV) Hydrolysis Products in the Preparation of Cerium Iodates: Electronic and Structural Aspects of $\mathrm{Ce}_{2}\left(\mathrm{IO}_{3}\right)_{6}\left(\mathrm{OH}_{x}\right)(x \approx$ 0 and 0.44)," Chemistry of Materials, 2004, 16, 1343-1349.

22. R. E. Sykora, A. C. Bean, B. L. Scott, W. Runde, and T. E. Albrecht-Schmitt, "New OneDimensional Uranyl and Neptunyl Iodates: Crystal Structures of 
$\mathrm{K}_{3}\left[\left(\mathrm{UO}_{2}\right)_{2}\left(\mathrm{IO}_{3}\right)_{6}\right]\left(\mathrm{IO}_{3}\right) \cdot \mathrm{H}_{2} \mathrm{O}$ and $\mathrm{K}\left[\mathrm{NpO}_{2}\left(\mathrm{IO}_{3}\right)_{3}\right] \cdot 1.5 \mathrm{H}_{2} \mathrm{O}$," Journal of Solid State Chemistry, 2004, 177, 725-730.

21. P. M. Almond and T. E. Albrecht-Schmitt, "Do Secondary and Tertiary Ammonium Cations Act as Structure-Directing Agents in the Formation of Layered Uranyl Selenites?," Inorganic Chemistry 2003, 42, 5693-5698.

20. A. C. Bean, B. L. Scott, T. E. Albrecht-Schmitt, and W. Runde, "Structural and Spectroscopic Trends in Actinyl Iodates of Uranium, Neptunium, and Plutonium," Inorganic Chemistry 2003, 42, 5632-5636.

19. T. E. Albrecht-Schmitt, P. M. Almond, and R. E. Sykora, "Cation-Cation Interactions in Neptunyl(V) Compounds: Hydrothermal Preparation and Structural Characterization of $\mathrm{NpO}_{2}\left(\mathrm{IO}_{3}\right)$ and $\alpha$ - and $\beta-\mathrm{AgNpO}_{2}\left(\mathrm{SeO}_{3}\right)$," Inorganic Chemistry 2003, 42, 3788-3795.

18. A. C. Bean, T. A. Sullens, W. Runde, and Thomas E. Albrecht-Schmitt, "Hydrothermal Assembly of Ni(II)/U(IV) Fluorides with One-, Two-, and Three-Dimensional Topologies," Inorganic Chemistry 2003, 42, 2628-2633.

17. R. E. Sykora and T. E. Albrecht-Schmitt, "Hydrothermal Assembly of a Polar OpenFramework Uranyl Vanadyl Hexaoxoiodate Constructed Entirely from Octahedral Building Units in the First Uranium Hexaoxoiodate: $\mathrm{K}_{2}\left[\left(\mathrm{UO}_{2}\right)_{2}(\mathrm{VO})_{2}\left(\mathrm{IO}_{6}\right)_{2} \mathrm{O}\right] \cdot \mathrm{H}_{2} \mathrm{O}$," Inorganic Chemistry 2003, 42, 2179-2181.

16. W. Runde, A. C. Bean, T. E. Albrecht-Schmitt, and B. L. Scott, "Structural Characterization of the First Hydrothermally Synthesized Plutonium Compound, $\mathrm{PuO}_{2}\left(\mathrm{IO}_{3}\right)_{2} \cdot \mathrm{H}_{2} \mathrm{O}$," Chem. Commun. 2003, 4, 478-479.

15. P. M. Almond and T. E. Albrecht-Schmitt, "Expanding the Remarkable Structural Diversity of Uranyl Tellurites: Hydrothermal Preparation and Structures of $\mathrm{K}\left[\mathrm{UO}_{2} \mathrm{Te}_{2} \mathrm{O}_{5}(\mathrm{OH})\right], \mathrm{Tl}_{3}\left\{\left(\mathrm{UO}_{2}\right)_{2}\left[\mathrm{Te}_{2} \mathrm{O}_{5}(\mathrm{OH})\right]\left(\mathrm{Te}_{2} \mathrm{O}_{6}\right)\right\} \cdot 2 \mathrm{H}_{2} \mathrm{O}, \beta-\mathrm{Tl}_{2}\left[\left(\mathrm{UO}_{2}\right)_{2}\left(\mathrm{TeO}_{3}\right)_{2}\right]$, and $\mathrm{Sr}_{3}\left[\mathrm{UO}_{2}\left(\mathrm{TeO}_{3}\right)_{2}\right]\left(\mathrm{TeO}_{3}\right)_{2}$," Inorganic Chemistry, 2002, 41, 5495-5501.

14. R. E. Sykora, S. M. McDaniel, D. M. Wells, and T. E. Albrecht-Schmitt, "Mixed-Metal U(VI) Iodates: Hydrothermal Syntheses, Structures, and Reactivity of $\mathrm{Rb}\left[\mathrm{UO}_{2}\left(\mathrm{CrO}_{4}\right)\left(\mathrm{IO}_{3}\right)\left(\mathrm{H}_{2} \mathrm{O}\right)\right], \mathrm{A}_{2}\left[\left(\mathrm{UO}_{2}\right)\left(\mathrm{CrO}_{4}\right)\left(\mathrm{IO}_{3}\right)_{2}\right](\mathrm{A}=\mathrm{K}, \mathrm{Rb}, \mathrm{Cs})$, and $\mathrm{K}_{2}\left[\left(\mathrm{UO}_{2}\right)\left(\mathrm{MoO}_{4}\right)\left(\mathrm{IO}_{3}\right)_{2}\right]$," Inorganic Chemistry, 2002, 41, 5126-5132. 
13. P. M. Almond, M. L. McKee, and T. E. Albrecht-Schmitt, "Unusual Uranyl Tellurites Containing $\left[\mathrm{Te}_{2} \mathrm{O}_{6}\right]^{4-}$ Anions and Three-Dimensional Networks," Angewandte Chemie 2002, 114, 3576-3579.

12. P. M. Almond, S. M. Peper, E. Bakker, and T. E. Albrecht-Schmitt, "Variable Dimensionality and New Uranium Oxide Topologies in the Alkaline-Earth Metal Uranyl Selenites $A E\left[\left(\mathrm{UO}_{2}\right)\left(\mathrm{SeO}_{3}\right)_{2}\right](A E=\mathrm{Ca}, \mathrm{Ba})$ and $\mathrm{Sr}\left[\left(\mathrm{UO}_{2}\right)\left(\mathrm{SeO}_{3}\right)_{2}\right] \cdot 2 \mathrm{H}_{2} \mathrm{O}$, , Journal of Solid State Chemistry 2002, 168, 358-366.

11. A. C. Bean, Y. Xu, J. A. Danis, T. E. Albrecht-Schmitt, and W. Runde, “Aqueous Reactions of U(VI) at High Chloride Concentrations: Syntheses and Structures of New Chloride Polymers," Inorganic Chemistry 2002, 41, 6775-6779.

10. R. E. Sykora, D. M. Wells, and T. E. Albrecht-Schmitt "Hydrothermal Preparation, Structure, and Electronic Properties of a Novel, Mixed-Metal Uranyl Chromato Iodate, $\mathrm{Cs}_{2}\left[\left(\mathrm{UO}_{2}\right)\left(\mathrm{CrO}_{4}\right)\left(\mathrm{IO}_{3}\right)_{2}\right]$," Inorganic Chemistry, 2002, 41, 2304-2306.

9. P. M. Almond and T. E. Albrecht-Schmitt, "Hydrothermal Syntheses, Structures, and Properties of the New Uranyl Selenites $\mathrm{Ag}_{2}\left(\mathrm{UO}_{2}\right)\left(\mathrm{SeO}_{3}\right)_{2}, M\left[\left(\mathrm{UO}_{2}\right)\left(\mathrm{HSeO}_{3}\right)\left(\mathrm{SeO}_{3}\right)\right](M=$ $\mathrm{K}, \mathrm{Rb}, \mathrm{Cs}, \mathrm{Tl})$, and $\mathrm{Pb}\left(\mathrm{UO}_{2}\right)\left(\mathrm{SeO}_{3}\right)_{2}$," Inorganic Chemistry 2002, 41, 1177-1183.

8. R. E. Sykora and T. E. Albrecht-Schmitt, "PTFE-Impregnation for Ion-Exchange with Layered Ce(IV) Fluorides," Chemistry of Materials 2001, 13, 4399-4401.

7. A. C. Bean and T. E. Albrecht-Schmitt, "Cation Effects on the Formation of the OneDimensional Uranyl Iodates $\mathrm{A}_{2}\left[\left(\mathrm{UO}_{2}\right)_{3}\left(\mathrm{IO}_{3}\right)_{4} \mathrm{O}_{2}\right](\mathrm{A}=\mathrm{K}, \mathrm{Rb}, \mathrm{Tl})$ and $\mathrm{AE}\left[\left(\mathrm{UO}_{2}\right)_{2}\left(\mathrm{IO}_{3}\right)_{2} \mathrm{O}_{2}\right]\left(\mathrm{H}_{2} \mathrm{O}\right)(\mathrm{AE}=\mathrm{Sr}, \mathrm{Ba}, \mathrm{Pb})$, J Journal of Solid State Chemistry 2001, 161, 416-423.

6. A. C. Bean, C. F. Campana, O. Kwon, and T. E. Albrecht-Schmitt, "A New Oxoanion: $\left[\mathrm{IO}_{4}\right]^{3-}$ Containing $\mathrm{I}(\mathrm{V})$ with a Stereochemically Active Lone-Pair in the Silver Uranyl Iodate Tetraoxoiodate( $\mathrm{V}), \mathrm{Ag}_{4}\left(\mathrm{UO}_{2}\right)_{4}\left(\mathrm{IO}_{3}\right)_{2}\left(\mathrm{IO}_{4}\right)_{2} \mathrm{O}_{2}$," Journal of the American Chemical Society 2001, 123, 8806-8810.

5. A. C. Bean, M. Ruf, and T. E. Albrecht-Schmitt, "Excision of Uranium Oxide Chains in the Novel One-Dimensional Uranyl Iodates $\mathrm{K}_{2}\left(\mathrm{UO}_{2}\right)_{3}\left(\mathrm{IO}_{3}\right)_{4} \mathrm{O}_{2}$ and $\mathrm{Ba}\left(\mathrm{UO}_{2}\right)_{2}\left(\mathrm{IO}_{3}\right)_{2} \mathrm{O}_{2}\left(\mathrm{H}_{2} \mathrm{O}\right)$," Inorganic Chemistry 2001, 40, 3959-3963.

4. R. E. Sykora,* M. Ruf, and T. E. Albrecht-Schmitt, "Organically Templated Zirconium Fluorides: Hydrothermal Syntheses, Structural Relationships, and Thermal Behavior of 
$\left(\mathrm{C}_{2} \mathrm{H}_{10} \mathrm{~N}_{2}\right) \mathrm{Zr}_{2} \mathrm{~F}_{10} \cdot \mathrm{H}_{2} \mathrm{O}$ and $\left(\mathrm{C}_{4} \mathrm{H}_{12} \mathrm{~N}_{2}\right) \mathrm{ZrF}_{6} \cdot \mathrm{H}_{2} \mathrm{O}$," Journal of Solid State Chemistry 2001, 159, 198-203.

3. A. C. Bean, S. M. Peper, and T. E. Albrecht-Schmitt, "Structural Relationships, Interconversion, and Optical Properties of the Uranyl Iodates, $\mathrm{UO}_{2}\left(\mathrm{IO}_{3}\right)_{2}$ and $\mathrm{UO}_{2}\left(\mathrm{IO}_{3}\right)_{2}\left(\mathrm{H}_{2} \mathrm{O}\right)$ : A Comparison of Reactions Under Mild and Supercritical Conditions," Chemistry of Materials 2001, 13, 1266-1272.

2. P. M. Almond, L. Deakin, A. Mar, and T. E. Albrecht-Schmitt, "Hydrothermal Synthesis, Structure, and Magnetic Properties of $\left(\mathrm{C}_{5} \mathrm{H}_{14} \mathrm{~N}_{2}\right)_{2} \mathrm{U}_{2} \mathrm{~F}_{12} \cdot 5 \mathrm{H}_{2} \mathrm{O}$ and $\left(\mathrm{NH}_{4}\right)_{7} \mathrm{U}_{6} \mathrm{~F}_{31}$," Journal of Solid State Chemistry 2001, 158, 87-83.

1. P. M. Almond, L. Deakin, A. Mar, and T. E. Albrecht-Schmitt, "Hydrothermal Synthesis, Structure, and Magnetic Properties of a Layered Organically Templated Uranium Aquofluoride: $\left[\mathrm{C}_{5} \mathrm{H}_{14} \mathrm{~N}_{2}\right]\left[\mathrm{U}_{2} \mathrm{~F}_{10}\left(\mathrm{H}_{2} \mathrm{O}\right)\right]$," Inorganic Chemistry 2001, 40, 886-890.

\section{General Summary}

This grant supported the exploratory synthesis of new actinide materials with all of the actinides from thorium to californium with the exceptions of protactinium and berkelium. We developed detailed structure-property relationships that allowed for the identification of novel materials with selective ion-exchange, selective oxidation, and long-range magnetic ordering. We found novel bonding motifs and identified periodic trends across the actinide series. We identified structural building units that would lead to desired structural features and novel topologies. We also characterized many different spectroscopic trends across the actinide series. The grant support the preparation of approximately 1200 new compounds all of which were structurally characterized.

\section{Selected abstract}

T. H. Bray, J. Ling, E.-S. Choi, J. S. Brooks, J. V. Beitz, R. E. Sykora, R. G. Haire, D. M. Stanbury, and T. E. Albrecht-Schmitt, "Critical Role of Water Content in the Formation and Reactivity of Uranium, Neptunium, and Plutonium Iodates Under Hydrothermal 
Conditions: Implications for the Oxidative Dissolution of Spent Nuclear Fuel," Inorganic Chemistry, 2007, 46, 3663-3668.

\begin{abstract}
The reactions of ${ }^{237} \mathrm{NpO}_{2}$ with excess iodate under acidic hydrothermal conditions result in the isolation of the $\mathrm{Np}(\mathrm{IV}), \mathrm{Np}(\mathrm{V})$, and $\mathrm{Np}(\mathrm{VI})$ iodates, $\mathrm{Np}\left(\mathrm{IO}_{3}\right)_{4}, \mathrm{~Np}\left(\mathrm{IO}_{3}\right)_{4} \cdot \mathrm{nH}_{2} \mathrm{O} \cdot \mathrm{nHIO} \mathrm{H}_{3}$, $\mathrm{NpO}_{2}\left(\mathrm{IO}_{3}\right), \mathrm{NpO}_{2}\left(\mathrm{IO}_{3}\right)_{2}\left(\mathrm{H}_{2} \mathrm{O}\right)$, and $\mathrm{NpO}_{2}\left(\mathrm{IO}_{3}\right)_{2} \cdot \mathrm{H}_{2} \mathrm{O}$, depending on both the $\mathrm{pH}$ and the amount of water present in the reactions. Reactions with less water and lower $\mathrm{pH}$ favor reduced products. While the initial redox processes involved in the reactions between ${ }^{237} \mathrm{NpO}_{2}$ or ${ }^{242} \mathrm{PuO}_{2}$ and iodate are similar, the low solubility of $\mathrm{Pu}\left(\mathrm{IO}_{3}\right)_{4}$ dominates product formation in $\mathrm{Pu}$ iodate reactions to a much greater extent than $\mathrm{Np}\left(\mathrm{IO}_{3}\right)_{4}$ does in the Np iodate system. $\mathrm{UO}_{2}$ reacts with iodate under these conditions to yield U(VI) iodates solely. The isotypic structures of the An(IV) iodates, $\mathrm{An}\left(\mathrm{IO}_{3}\right)_{4}(\mathrm{An}=\mathrm{Np}, \mathrm{Pu})$ are reported and consist of one-dimensional chains of dodecahedral An(IV) cations bridged by iodate anions. The structure of $\mathrm{Np}\left(\mathrm{IO}_{3}\right)_{4} \cdot \mathrm{nH}_{2} \mathrm{O} \cdot \mathrm{nHIO}$ is constructed from $\mathrm{NpO}_{9}$ tricapped trigonal prisms that are bridged by iodate into a polar threedimensional framework structure. Second-harmonic generation measurements on a polycrystalline sample of the Th-analog of $\mathrm{Np}\left(\mathrm{IO}_{3}\right)_{4} \cdot \mathrm{nH}_{2} \mathrm{O} \cdot \mathrm{nHIO}_{3}$ reveals a response of approximately $12 \times \alpha-\mathrm{SiO}_{2}$. Single crystal magnetic susceptibility measurements of $\mathrm{Np}\left(\mathrm{IO}_{3}\right)_{4}$ show magnetically isolated $\mathrm{Np}(\mathrm{IV})$ ions.
\end{abstract}

\title{
Remaining Funds
}

All funds have been expended. 